\title{
The Process of Conflict Resolution in Public Project Disputes: Analysis by Settlement Methods*
}

\begin{abstract}
Hunmin Kim**
Abstract: This study examines thirteen recent public dispute cases in Korea with the objective of analyzing the process of conflict resolution and thereby assessing the role of alternative dispute resolution (ADR) in public disputes. The focus is on dispute cases related to development of, or site selection for, public projects. Based on detailed accounts of events, the nature of the conflict, parties involved, pattern of actions taken, and final outcomes are analyzed. Only five cases were settled by ADR methods, indicating that ADR is rather ineffective in public conflicts. ADR seems to work better in locally confined, structured conflicts where participatory processes are used. An identifiable pattern in attempts at ADR is that ad-hoc committees are formed but often fail to reach agreement or are seen as lacking legitimacy, authority, and impartiality. Policy implications drawn from this study are that a higher priority should be given to developing community-based conflict resolution programs, that ADR should be incorporated into local government regulations to acquire greater legitimacy, and that conflict prevention procedures are a prerequisite for the success of conflict resolution programs.
\end{abstract}

Keywords: Conflict Resolution, Public Disputes, Public Project Siting, Alternative Dispute Resolution, Consensus Building

\section{INTRODUCTION}

Drawing mainly on the experiences of North American and European societies over the last thirty years, consensus-based approaches to resolving social conflicts

* This work was supported by a 2003 Ewha Womans University Research Grant.

** Hunmin Kim is a professor in the Department of Public Administration at Ewha Womans University. She received a Ph.D. in urban planning from Harvard University. Her research interests are world city development, local government innovation, and public conflict resolution.Email: hmkim@ewha.ac.kr.

Manuscript received July 2008; out for review July 2008; review completed August 2008; accepted October 2008.

The Korean Journal of Policy Studies, Vol. 23, No. 2, 147-170 (2009)

(C) 2009 by the GSPA, Seoul National University 
have been promoted by many scholars and practitioners. Known under the generic term of alternative dispute resolution (ADR), application of these methods in other countries, where research and practice in the subject is much more recent and limited in numbers, is being actively pursued.

Korea is one of those countries, confronted by growing outbreaks of complex social conflicts triggered by controversial public policies. Especially since the democratization movement in the late 1980s, citizens have become much more active in speaking out against policy measures that run counter to their interests. In an attempt to deal with the proliferation of public disputes, the central government has started to devise a program to promote and facilitate nonadversarial methods of resolving public disputes. It is still at an embryonic stage, undergoing public discussion and evaluation.

In order to design an effective conflict resolution procedure suitable to Korean society, an in-depth understanding of the nature of public disputes and the process of conflict resolution is a prerequisite. There is a need to guard against the tendency to simply mimic programs and methods applied in western society. During the past ten years, studies on public disputes in Korea have provided some useful insights (Choe et al., 2003; Chun, 2003; Jeon, 2002; Jin, 2004; Ju, 2004; Ju and Hong, 2003; Jung, 2000; Kim, 2002; Kim, 2001a, 2001b; Kim, 1997; Kim, 2004; Kim, 2000; Kwon, 1998; Lee and Kwon, 1998; Park, 2000; Park, 1999; Soh, 1999; Yim and Chang, 2004; Yoo et al., 2004). However, most of the studies are based on only one or two cases and therefore have limitations in identifying general patterns and characteristics of how conflicts are generated and settled.

This article examines thirteen recent public disputes in Korea with the objective of analyzing the process of conflict resolution based on methods of settlement and final outcomes. Among the various public dispute cases, this study selected those related to development or siting of public projects such as waste disposal facilities, express railways, industrial complexes, crematoria, and land reclamation, which are the most frequently occurring disputes. Utilizing information in research articles and media reports of the cases, this study analyzes the nature of the conflicts, parties involved, roles of the government, patterns of actions taken, and final outcomes in order to identify some general patterns and characteristics of conflict resolution processes. A modified version of the framework presented by Lan (1997) is applied in analyzing the cases. Based on the findings, this article assesses the role of ADR in Korean public disputes and draws implications for measures to improve and extend its use. Before the case analysis is presented, ADR procedures and models are briefly discussed, followed by a presentation of the framework for conflict resolution utilized in this study. 


\section{ANALYTICAL APPROACHES FOR CONFLICT RESOLUTION}

\section{ADR Procedures and Models}

Conflict resolution has been a subject of research in a wide range of fields, such as environmental studies, labor relations, social psychology, urban planning, and international relations. Most of the literature deals with various forms of ADR as effective procedures for conflict resolution. The different procedures can be divided into consensus-based processes and quasijudicial processes (Emerson et al., 2003). Consensusbased processes are collaborative decision-making techniques such as negotiation, conflict assessment, facilitation, mediation, conciliation, negotiated rulemaking, and policy dialogues. Quasijudicial processes provide disputing parties with expert opinion and include procedures like early neutral evaluation, minitrials, summary jury trials, settlement judges, fact finding, and arbitration.

Within ADR there can be variations in the approach to decision making. The pluralistic bargaining model emphasizes "enlightened self-interest" to achieve balance of power and outcome among contenders (Fisher, Ury, and Patton, 1991; Rubin, 1995). The utilitarian decision model seeks optimization or maximization of net benefit based on expected offers or concessions (Raiffa 1982). The problem-solving approach perceives conflict as a problem that should be solved through analytical and collaborative exercises (Glasbergen, 1995; Mitchell and Banks, 1996).

Although the prevalent views on ADR procedures are mostly positive, there are some warnings about their shortcomings. Tactical, psychological, institutional, organizational, or structural barriers in negotiation can preclude successful conflict resolution (Arrow et al., 1995). ADR tends to be devoid of cultural context (Pedersen and Jandt, 1996; Ross, 1993) and has limited effectiveness in dealing with deep and fundamental political conflict and imbalance of power (Amy, 1990). Its uses have not been matched with sufficient evaluation (Birkhoff and Lowry, 2003), and its advantage over adjudication may be exaggerated (Fiss, 1984).

\section{A Framework for Evaluating Conflict Resolution in Public Disputes}

Prior to designing an appropriate conflict resolution program, we need to understand the nature of conflict and how public conflicts arise, proceed, and are resolved. To do so, we need an analytical framework for conflict resolution relevant to public disputes, and Lan (1997) provides a concise but comprehensive framework. In analyzing the Korean public dispute cases, this study applies Lan's framework with some modification as presented in Table 1 . 
Table 1. Framework for Conflict Resolution

\begin{tabular}{|c|c|}
\hline Nature of conflict & $\begin{array}{l}\text { Subjective } \\
\text { Objective } \\
\text { - competitive } \\
\text { - cooperative } \\
\text { - mixed }\end{array}$ \\
\hline Type of conflict & $\begin{array}{l}\text { Mostly structured } \\
\text { Mostly unstructured }\end{array}$ \\
\hline Roles of actors in the conflict & $\begin{array}{l}\text { Parties to conflict } \\
\text { Neutrals (mediator, arbitrator, etc.) }\end{array}$ \\
\hline Conventional conflict resolution strategies & $\begin{array}{l}\text { Litigation and executive orders } \\
\text { Punitive sanctions on conflictual behavior } \\
\text { Avoiding conflict escalation } \\
\text { Sit-ins, demonstrations, rallies, petitions, hunger strikes }\end{array}$ \\
\hline Alternative dispute resolution strategies & $\begin{array}{l}\text { Common goal establishment } \\
\text { Consensus-building } \\
\text { Joint problem-solving } \\
\text { Negotiation } \\
\text { Informal arbitration } \\
\text { Mediation } \\
\text { Nonbinding minitrials } \\
\text { Conflict enlargement } \\
\text { Conflict containment } \\
\text { Partnering } \\
\text { Outlets for emotions }\end{array}$ \\
\hline
\end{tabular}

Source: Modified from Lan (1997)

In subjective conflict, the conflict is not real but perceived by the stakeholders. Lan suggests that in subjective conflicts communication, provision of scientific information, and rapport-building can be effective in resolving the conflict. In objective conflict, the conflict actually exists. It can be a competitive conflict, in which the benefits and losses amount to a zero-sum between the parties to the conflict. In a cooperative conflict, parties to the conflict face similar gains or losses, making a win-win result possible if proper cooperation is attained. Citizen participation, empowerment, partnerships, information-sharing, and the like are ideal for cooperative conflicts (Lan, 1997, p. 29). Mixed-type objective conflicts have both competitive and cooperative gains and losses for the stakeholders.

Types of conflicts presented by Lan (1997) are much simpler but more useful when applied to public disputes than those discussed in Deutsch (1973). Parties in unstructured conflict are not bound by any rules, acting impulsively and emotionally because 
agreed-upon rules for resolution are insufficient or nonexistent. Parties in structured conflicts go by rules, social norms, and ethical standards, and they know "how, where, and when to seek the resolution of the conflict" (Lan, 1997, p. 30). Rule of law and organizational policies are major methods for resolving structured conflicts in the public sector. Many public conflicts are partially structured, in that there are norms, rules, and regulations to guide some actions for conflict resolution, but other actions have no standards to go by.

Conventional strategies for conflict resolution mostly resort to decisions made by the courts or by senior public officials. In unstructured conflicts, conventional strategies typically involve protests, demonstrations, sit-ins, rallies, petitions, and often more violent forms of resistance. ADR strategies have been receiving greater attention and are often seen as more efficient and effective than conventional methods, but the parties to conflict first have to agree to their use and be aware of the basic techniques. The government can take any of the three roles in conflict resolution-an observer, a third-party neutral, or a stakeholder-but it is important to recognize which role is most appropriate to the situation (Lan, 1997, p. 32). Following the basic framework in Table 1, public dispute cases in Korea are analyzed.

\section{ANALYSIS OF DISPUTE CASES}

The thirteen cases selected for this research are relatively recent public disputes related to development or siting of public projects. They are cases in which the central or local government was a party to the conflict, which have been subjects of research or reported in the mass media, and which have been settled one way or the other. These common aspects give some coherence in comparison, make findings more meaningful, and provide sufficient information for analysis. Four cases are macrolevel or national conflicts in that the supporters and opponents of the public projects were spread across the nation (High-Speed Railway on Cheonsung Mountain, Buan Wido Nuclear Waste Repository, Saemangeum Tideland Reclamation, and Dong-gang Dam Construction). The remaining nine are micro-level or local conflicts.

For each case the author recorded the milestones of the conflict, starting from the conception of the public project, to the eruption of conflict, the settlement procedures, and the final outcome of the case. Particular attention was paid to the dynamics of action and reaction and the formation of committees involved in the settlement. Due to space constraints only two exemplary cases are presented as illustrations in Appendix Tables 1 and 2.

The case of Cheonsung Mountain (see Appendix Table 1) gained national attention 
as Buddhist monks led the resistance movement. The unprecedented length of the hunger strike staged by a Buddhist nun triggered a sympathetic movement by citizens to save the nun. The president and the prime minister intervened directly or indirectly. The fervor subsided when an agreement was reached to conduct a joint investigation of the project's environmental impact. The joint investigation found that the proposed railway route cutting across the mountain would not cause serious environmental damage. After the report was released, the case failed to summon any further large-scale attention. The Korea Railroad Corporation filed a suit against the nun and the court found her guilty of obstructing public work.

The Gunpo Waste Incinerator case (see Appendix Table 2) is one of numerous disputes encountered by local governments concerning waste incinerators. It shows that site selections made by a committee composed of citizen representatives tend to be challenged by residents, raising the issue of the authority and legitimacy of citizen representatives.

For each of the thirteen public project cases, the author tried to identify the nature and type of conflict, the stakeholders, and the conventional and ADR strategies of conflict resolution, following the modified version of Lan's (1997) framework presented in Table 1. Additional factors related to this framework were examined, such as whether the project is an unwanted facility subject to the NIMBY ("not in my back yard") syndrome, the type of public facility, the scale of the conflict, and whether some form of citizen participation was used in the ADR strategies. In analyzing the role of actors in the conflict, attention was paid to the types of governments involved, the levels of governments in intergovernmental conflicts, and whether residents were split into contending parties. The result of the analysis is presented in Tables 2 and 3 grouped by the method of settlement or final outcome-those resolved by the conflicting parties, those adjudicated by the court, and those in which the projects were withdrawn. Greater details on the parties involved, conventional and ADR strategies, and the final outcome for each case can be seen in Appendix Table 3.

\section{Characteristics of Conflict Resolution}

The conflict in three cases can be considered subjective, because the opponents' perceptions of damage from the public projects were largely unfounded or based on low probabilities. The extent of risks from the nuclear waste repository in Buan, and the damage to the environment or to temple activities from the tunnels of the Seoul Beltway and the Express Railway were not clearly known. Each of these cases had a different outcome.

The other ten cases can be considered objective conflicts involving prospects of 


\begin{tabular}{|c|c|c|c|c|c|c|c|c|c|c|c|c|c|}
\hline 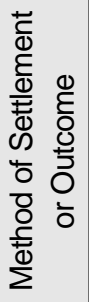 & $\begin{array}{l}\bar{\Phi} \\
\stackrel{0}{0} \\
\stackrel{0}{\mathscr{d}} \\
\underline{\Phi}\end{array}$ & 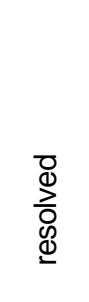 & 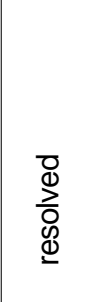 & $\begin{array}{l}\bar{D} \\
\stackrel{0}{0} \\
\stackrel{0}{\mathscr{D}} \\
\underline{\Phi}\end{array}$ & 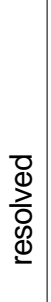 & $\begin{array}{l}\frac{8}{\frac{0}{2}} \\
\frac{2}{2} \\
\frac{5}{2} \\
0\end{array}$ & $\begin{array}{l}\frac{D}{0} \\
\frac{2}{2} \\
\frac{5}{5} \\
0 \\
0\end{array}$ & $\begin{array}{l}\frac{0}{\frac{0}{5}} \\
\frac{2}{2} \\
\frac{7}{2} \\
0\end{array}$ & $\begin{array}{l}\frac{\bar{d}}{5} \\
\frac{2}{5} \\
\frac{5}{0}\end{array}$ & $\begin{array}{l}\frac{8}{0} \\
\frac{1}{2} \\
\frac{7}{5} \\
8 \\
0\end{array}$ & $\begin{array}{l}\overline{0} \\
\frac{d}{0} \\
\frac{0}{0} \\
\mathbb{0} \\
\frac{0}{0} \\
\frac{0}{0} \\
\frac{0}{2}\end{array}$ & 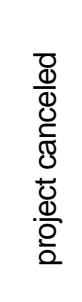 & 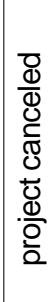 \\
\hline 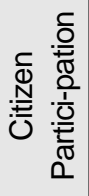 & & $\stackrel{>}{\Perp}$ & 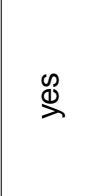 & $\stackrel{\infty}{\perp}$ & $\stackrel{\mathscr{N}}{\stackrel{2}{\nu}}$ & $\stackrel{\mathscr{\Perp}}{>}$ & & & & & & & $\stackrel{\mathscr{D}}{\stackrel{\infty}{2}}$ \\
\hline 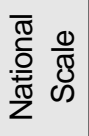 & & & & & & & $\stackrel{\mathscr{\Perp}}{\curvearrowright}$ & & & $\stackrel{\infty}{\curvearrowright}$ & & $\stackrel{\Perp}{\stackrel{2}{2}}$ & 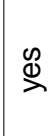 \\
\hline 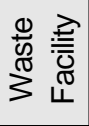 & $\stackrel{\searrow}{\Perp}$ & $\stackrel{\Perp}{\stackrel{2}{2}}$ & $\stackrel{\infty}{\stackrel{\infty}{2}}$ & 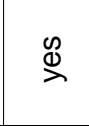 & & $\stackrel{>}{\Perp}$ & & & & & & & $\stackrel{\mathscr{N}}{\stackrel{2}{2}}$ \\
\hline 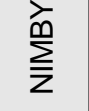 & $\stackrel{\mathscr{D}}{\stackrel{2}{2}}$ & $\stackrel{\searrow}{\Perp}$ & $\stackrel{\infty}{\stackrel{\infty}{2}}$ & $\stackrel{\searrow}{\searrow}$ & & $\stackrel{\Perp}{\stackrel{2}{2}}$ & & $\stackrel{\infty}{\searrow}$ & $\stackrel{\infty}{\stackrel{\infty}{2}}$ & & & & $\stackrel{\mathscr{N}}{\stackrel{2}{2}}$ \\
\hline 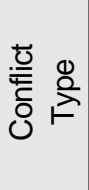 & 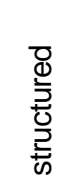 & 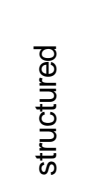 & 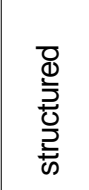 & 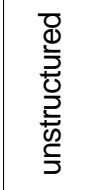 & 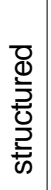 & 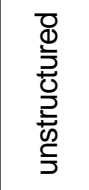 & 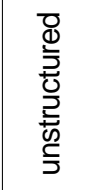 & 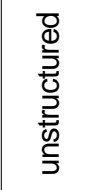 & 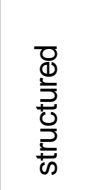 & 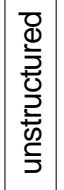 & 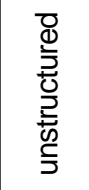 & 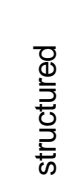 & 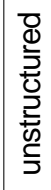 \\
\hline 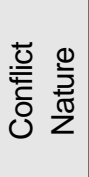 & 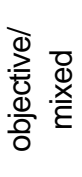 & 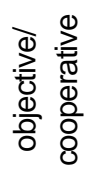 & 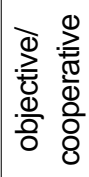 & 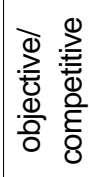 & 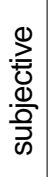 & 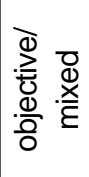 & 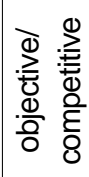 & 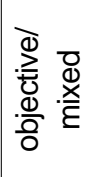 & 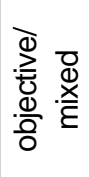 & 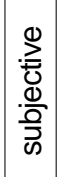 & 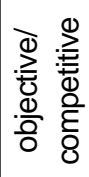 & 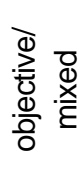 & 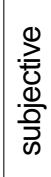 \\
\hline 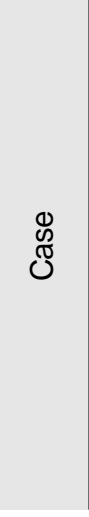 & 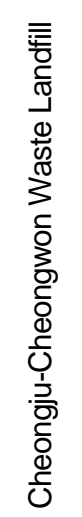 & 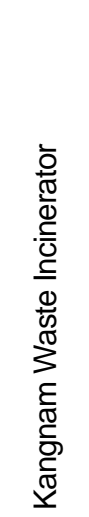 & 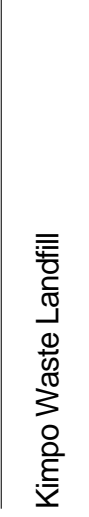 & 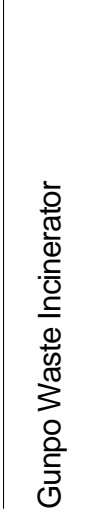 & 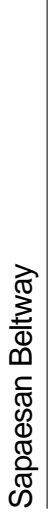 & 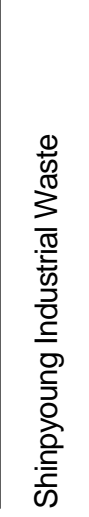 & 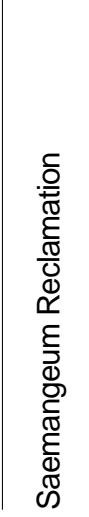 & 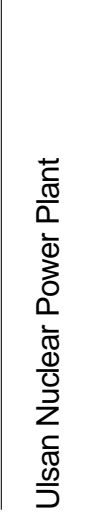 & 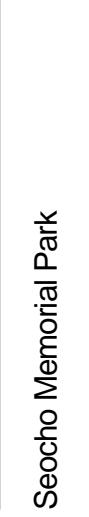 & 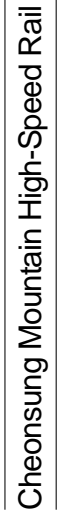 & 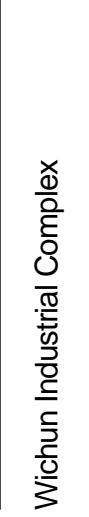 & 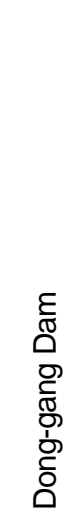 & 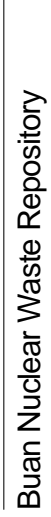 \\
\hline
\end{tabular}




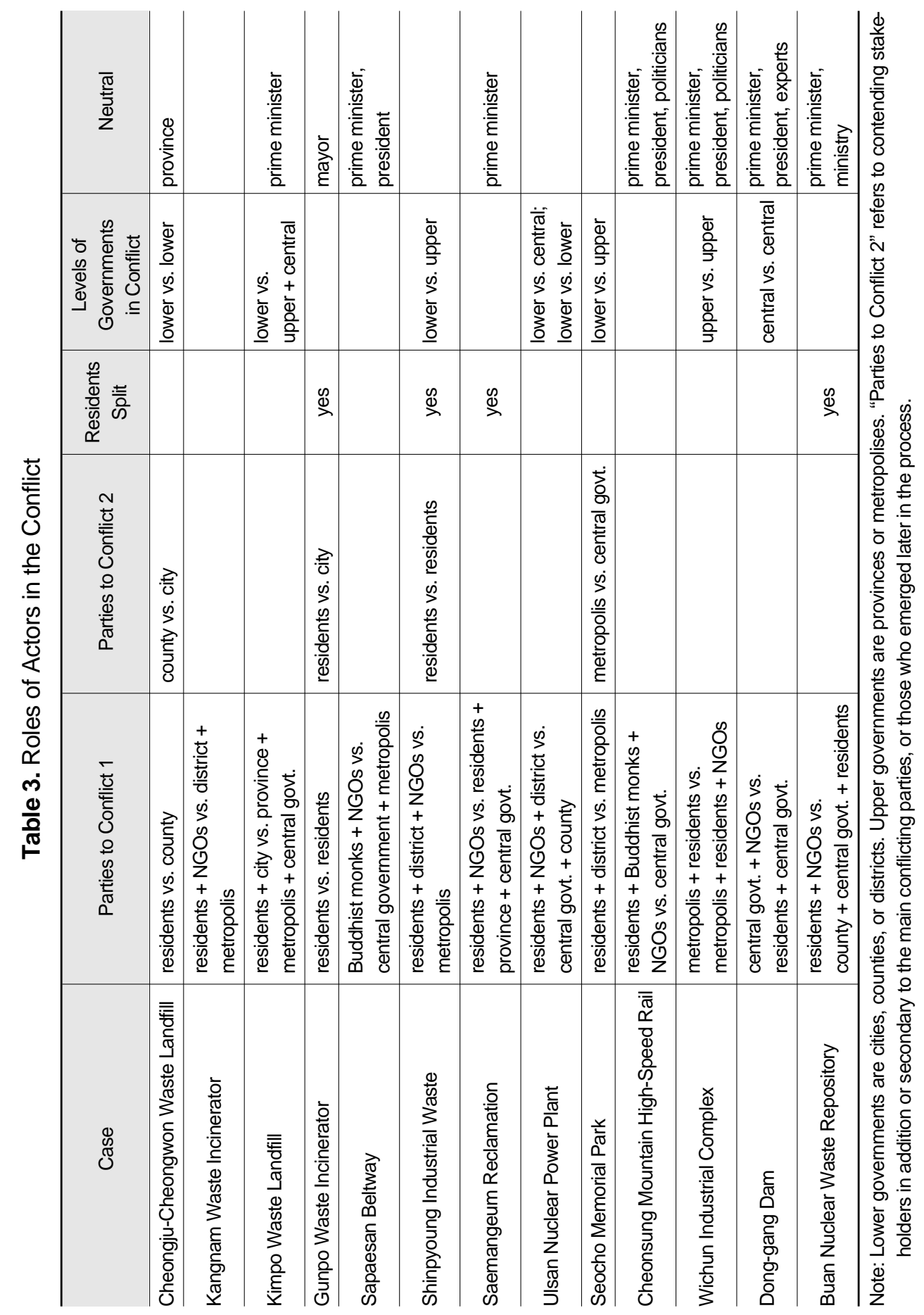


relatively well substantiated losses and gains to the parties to the conflict. Aggravation of pollution in the Nakdong River in Busan from the Wichun industrial complex in Daegu city, and the damaging effect of reclamation on the ecosystem of Saemangeum tideland were noted by experts in the field. Dire consequences of accidents in nuclear power plants have been reported internationally. Waste disposal facilities and crematories are locally unwanted land uses known to cause nuisances and property devaluation. The objective conflicts that were mostly competitive, but in which compensation was offered to the opposing parties, were categorized as mixed conflicts. Only two cases could be considered as cooperative conflicts where gains and losses accruing to each party were mostly noncompetitive. Both of these cases were successfully resolved.

If most of the actions taken, whether conventional or ADR strategies, had some rules and predetermined procedures to follow, the case was categorized as structured conflict. Among the conventional methods, petitions and litigations are structured actions while sit-ins, demonstrations, and strikes are unstructured actions. Among the ADR processes, those that have some rules to follow such as joint committees and public hearings are considered to be structured, while informal meetings and other impromptu arrangements are unstructured actions. Although the sample is too small for statistical testing, Table 2 suggests that structured conflicts are more likely to be resolved by ADR while unstructured conflicts are likely to be settled by court ruling or project cancellation.

Involving citizens in ADR strategies seems to increase the chances for resolution. Table 2 shows that four out of five cases that were resolved by ADR used some form of participatory procedures in which citizens could formally express their opinions or take part in decision making. In these cases, citizen representatives participated in site selection, project management, or public forums.

The majority of the projects were unwanted public facilities - six waste management facilities, one nuclear power plant, and one public crematory. One can see from Table 2 that disputes over urban residential waste management facilities tend to have better chances of resolution than those involving industrial or nuclear waste management facilities.

Conflicts that blew up to a national scale were settled either by court ruling or by canceling the projects. This indicates that ADR processes are not effective for conflicts in which the supporters and opponents of the public projects have a national following.

In all cases the parties to the conflict lived near proposed project sites and opposed the government agencies in charge of the projects. In the cases of Kimpo, Shinpyoung, Ulsan, and Seocho, municipal governments took the side of the residents, opposing projects proposed by upper-level governments. Frequently environmental NGOs joined on the side of the residents. Table 3 indicates that when NGOs are a party to conflict, set- 
tlement is likely to be adjudicated by the court or consist of the project being rescinded. Whether residents are split into two contending sides or united in a common interest does not seem to be correlated with a particular method of settlement.

Intervention by top government executives like the prime minister and the president does not seem to affect the outcome. This suggests that top executives are not particularly effective in building consensus or inducing resolution through ADR processes. Especially the prime minister's office, which is in charge of mediating intergovernmental conflicts, does not seem to function effectively in conflict resolution. If any notable role is played by top executives, it is in canceling controversial projects.

Seven cases involved intergovernmental conflicts, as can be seen in Table 3. All types and levels of government were involved in project disputes - cities, counties, districts, provinces, metropolises, and the central government. Whether the same levels of governments were in conflict with each other does not seem to be associated with any particular method of settlement. It is interesting to note that when two big government agencies conflict over a public project, it is likely to be canceled. That was the case when Busan metropolis disputed with Daegu metropolis over the Wichun industrial complex. In the case of Dong-gang dam, two central government ministries, the Ministry of Environment and the Ministry of Construction and Transportation, were in contention.

A common characteristic in many of these conflicts is that they were largely triggered by government agencies making or changing policies without the knowledge or participation of the affected citizens (Lee and Kwon, 1998; Park, 2000; Kim, 2000; Kwon, 1998; Baeg, 2002; Jeon, 2002; Kim, 2001a; Kim, 2001b; Yim and Chang, 2004; and others). Just to mention a few, Cheongwon County agreed with the neighboring city of Cheongju to have a landfill in the county for locally generated waste without any consultation with the residents (Yim and Chang, 2004). The landfill in Kimpo was originally intended for household wastes only, and residents were enraged to find out that the Ministry of Environment had decided to treat industrial wastes there as well (Jin, 2004). Without providing opportunities for the residents to express their opinions, the mayor of Ulju in the Ulsan area simply announced the construction of new nuclear power plants in addition to what exist there (Kim, 2001a). In trying to deal with opposition to public projects, government officials often aggravate the conflict with policy blunders, indecisiveness, or overblown promises that cannot be fulfilled (Soh, 1999; Jung, 2000; Jin, 2004; Kim, 2004).

\section{Patterns of Conflict Resolution Processes}

All the cases resorted to conventional methods of conflict resolution, often including violent and illegal actions, but ADR processes were applied as well (see Appendix 
Table 3). A typical process is that in early stages of the conflict mostly conventional strategies are used, but as conflict escalates the parties attempt to use ADR methods. The ADR procedures are mostly ad-hoc and piecemeal arrangements in that they tend to be made hastily as a reaction to escalating protests.

Various forms of ADR were used in trying to resolve the conflicts. Negotiations, joint investigations, joint problem-solving, and other procedures were attempted mostly through ad-hoc committees composed largely of specialists and government officials with only a few citizen representatives. Most of them were informally done with very few predetermined rules or procedures and resulted in failure. In the Dong-gang dam and the Buan nuclear waste repository cases, efforts at collaborative problemsolving failed. In the disputes over the Sapaesan tunnel and the Cheonsung Mountain tunnel, joint committees composed of representatives from each party formed to examine alternate routes failed to find agreeable alternatives.

In the cases of the Shinpyoung and Gunpo incinerators and the Saemangeum reclamation project, agreements were made in joint committees but they were not accepted by the rest of the parties to the conflict. Even when the participants in the joint committees were recommended by the parties to the conflict, the committees were frequently challenged on their representativeness and impartiality and were not accepted as legitimate.

In the case of Memorial Park, the city of Seoul was able to reach an agreement with Seocho District, which agreed to the park on the condition that the capacity of the crematory be substantially reduced and that a public hospital be built in the park. However, the hospital would have been a breach of designated land use and was consequently opposed by the Ministry of Construction and Transportation.

The ADR measures attempted in the dispute cases mostly failed because the parties to the conflict and the neutral parties were largely unaware of the skills and techniques necessary for proper application (Lee and Kwon, 1998). The measures were carried out sporadically and randomly, without much preparation, mainly for the purpose of appeasing the aggrieved party. Consequently, they often turned out to be no more than symbolic gestures. Moreover, because the ADR meetings were held when hostility was very strong, they ended up only reaffirming each party's position, as was the case in Buan and Saemangeum. The Kimpo incinerator case is an exception, for negotiations between the government agency and the residents were held 26 times over a period of more than a year (Jin, 2004).

Of the thirteen disputes over public projects, five were resolved, five were adjudicated in court, and three were repealed by executive decisions. In two of the resolved cases, executives in neutral positions played arbitrating roles for conflict resolution. Therefore, in only three cases-Cheongju and Cheongwon region landfill, Kimpo 
landfill, and Kangnam incinerator-did the conflicting parties themselves achieve a consensus-based resolution. These were all micro-level disputes related to urban residential waste disposal facilities. The president intervened in four cases and the prime minister's office in seven cases, but in only one case did this contribute to a successful resolution. These outcomes indicate that ADR or nonconventional methods of conflict resolution are not properly functioning in Korea. In fact, it is more accurate to say that proper ADR procedures are largely unfamiliar to Korean society.

\section{POLICY IMPLICATIONS}

This study examined the processes in which conflicts were generated and dealt with in thirteen public project disputes in Korea, focusing on the actions taken to resolve the conflicts. Only five cases could be considered to have been resolved by ADR processes - three by consensus-based methods and two by some form of arbitration.

A number of patterns can be identified from an analysis of the cases, although caution should be applied in generalization. ADR is likely to be more effective in structured and cooperative conflicts, in local rather than national conflicts, and in conflicts over residential rather than industrial or nuclear waste management facilities. Uses of participatory procedures to provide channels for citizens to make inputs and share decision making seem to improve the chances for ADR-induced settlements. ADR is less likely to be successful in conflicts where an NGO is involved as a party to conflict and where large, powerful government agencies are in opposing positions. Interventions by the prime minister or president do not necessarily improve the chances for successful ADR.

Commonly observed aspects were the severe lack of information sharing and very limited official channels for citizens and government agencies in dealing with public conflicts. Conventional methods such as petitions, litigation, executive orders, and demonstrations are predominantly used for conflict resolution. Attempts at nonconventional approaches or ADR usually involve forming ad-hoc committees to work out agreements, but they often fail to reach agreements or are challenged as lacking legitimacy, authority, and impartiality. ADR techniques are largely unknown to government officials and parties to the conflict.

A number of policy implications can be suggested, based on these observations, to make ADR more effective. First, because ADR processes are still largely unfamiliar and ineffective in public disputes in Korea, ADR should be used more actively, but selectively, on cases that are conducive to its success. Greater successes for ADR would build trust and respect for it. ADR is more likely to succeed in locally confined, 
objective, and structured conflicts using participatory procedures. Absence of NGOs or large government agencies pitted against each other would be an additional condition favorable to ADR. This implies that greater priority should be given to developing community-based ADR processes than to a national program. More attention should be paid to identifying the necessary measures to foster community-based conflict prevention and resolution programs.

Second, it has been observed that stakeholders often reject the results of ADR processes, questioning their legitimacy and representativeness. This could be a reason for the limited effectiveness of ADR methods found in this study. Measures to give greater authority to ADR and to make its outcomes binding are urgently needed so that conflicting parties do not challenge its results. Incorporating specific ground rules and procedures for ADR into the local regulatory system would make the practice of ADR more legitimate and binding. To be accepted by the public, conflict resolution programs should be given a legal basis and provided by impartial agencies with sufficient authority. A related implication is that public investment in ADR training for government officials, NGOs, and citizens should be stepped up, especially at local levels. ADR practitioners must possess the proper mindset and skills in order to familiarize parties to conflict with ADR and persuade them to abide by its results.

Third, public disputes in Korea often involved the highest government executive offices. This is undesirable, not only because their interventions do not seem to be particularly helpful to ADR, but also because it will reinforce the inclination to escalate local disputes to national levels. The tendency to rely on top national officials could be due to lack of trust in local governments, which in turn is caused by their lack of authority and means for conflict resolution. More authority to deal with public disputes, and to make policy decisions in general, should be invested in local governments to enable them to take more proactive roles in the governance of conflict resolution.

Last, the public disputes examined in this study suggest that preventive measures are urgently needed. Most of the disputes were triggered by policies formulated and implemented without providing accurate information to the citizens affected by the policies. When policy formulation is not consensus-based, consensus-based approaches to resolving the conflict generated by the policy are not likely to be effective. As long as people are unfamiliar with consensus-based policy formulation, they can only be distrustful of consensus-based procedures to resolve policy conflicts.

In such a context, ADR programs applied at the resolution stage - that is, after conflict has erupted and escalated-are not likely to function properly. Therefore, in designing programs to deal with public disputes in Korea, conflict prevention should be a higher priority than conflict resolution. Sufficient investment of time and effort should be made in exploring and designing effective preventive procedures before 
launching programs aimed at the resolution stage of public disputes. This includes changing government agencies' attitudes towards the citizens to promote more collaborative efforts in policy making. Preventive measures such as meaningful citizen participation, wider sharing of accurate information, and assessment of potential conflicts at the early stages of policy formulation should be actively undertaken. Conflict resolution programs can be made more effective by developing effective conflict prevention programs.

\section{REFERENCES}

Amy, D. J. (1990). Environmental dispute resolution: The promise and the pitfalls. In N. J. Vig and M. E. Kraft (Eds.), Environmental policy in the 1990s. Washington, DC: CQ Press.

Arrow, K. J., Mnookin, R. H., Ross, L., Tversky, A., \& Wilson, R. B. (1995). Barriers to conflict resolution. New York: W.W. Norton \& Company.

Baeg, J. (2002). A study on the memorial park in Seoul metropolitan. Korean Society and Public Administration, 13(2): 191-216.

Birkhoff, J. E., \& Lowry, K. (2003). Whose reality counts? In R. O'Leary and L. B. Bingham (Eds.), The promise and performance of environmental conflict resolution. Washington, DC: Resources for the Future.

Choe, H., Hong, S., \& Ju, G. (2003). Grounded theory for social conflict: The case of dam construction. Korean Public Administration Review, 37(4): 169-193.

Chun, J. (2003). Political economy of Saemangeum tideland reclamation project through advocacy coalition framework. Korean Society and Public Administration, 14(2): 207-234.

Deutsch, M. (1973). The resolution of conflict: Constructive and destructive processes. New Haven: Yale University Press.

Emerson, K., Nabatchi, T., O'Leary, R., \& Stephens, J. (2003). The challenges of environmental conflict resolution. In R. O'Leary and L. B. Bingham (Eds.), The promise and performance of environmental conflict resolution. Washington, DC: Resources for the Future.

Fisher, R., Ury, W., \& Patton, B. (1991). Getting to yes: Negotiating agreement without giving in. New York: Penguin Books.

Fiss, O. M. (1984). Against settlement. The Yale Law Journal, 93: 1073-1090.

Glasbergen, P. (1995). Managing environmental disputes: Network management as an alternative. Dordrecht: Kluwer Academic Publishers.

Jeon, J. (2002). An analysis on the structure of locational conflicts: Focused on the 
case of Kangnam incinerator. Korean Society and Public Administration, 13(3): 239-263.

Jin, J. (2004). Intra-cohesion of an organization and conflict behavior: The Sudokwon landfill site. Korean Public Administration Review, 38(6): 71-92.

$\mathrm{Ju}, \mathrm{J}$. (2004). The coordination mechanism and cooperative rules in the policy conflicts with governments: Comparing the Dong-gangdam project with the Saemangeum project. The Korea Public Administration Journal, 13(3): 51-84.

Ju, J. B., \& Hong, S. M. (2003). The policy conflict and coordination mechanism in the development process of water resources. Journal of the Korean Urban Management Association, 17(1): 241-271.

Jung, J. (2000). Group conflict and government: A case study on the conflict over development and conservation Saemangeum tideland reclamation project. The Korea Public Administration Journal, 9(4): 79-104.

Kim, C. (2002). An analysis on the implementation factors affecting national projects: Focusing on the tideland reclamation project of Saemangeum. Korean Society and Public Administration, 13(1): 53-80.

Kim, D. (2001a). A study on the conflict raising factors of siting conflict between local government and public: The siting conflict case of Ulsan nuclear power plant. Korean Policy Studies Review, 10(1): 165-189.

(2001b). A study on the factors of conflict corresponding to procedural stages in the location policy of unfavorable facilities: Cases of conflict in siting waste treatment facilities. The Summer Conference of the Korean Association for Public Administration: 599-616.

Kim, H. (1997). The role of citizen participation in siting unwanted public facilities. Korean Review of Public Administration, 2(2): 277-296.

Kim, K. (2004). A study on resident resistance in the process of policy implementation: The case for siting of Buan nuclear waste repository. Korean Policy Studies Review, 13(5): 159-185.

Kim, P. (2000). Efficient solution of dispute in the unwanted facility: The case of the Goon Po garbage incinerator. Negotiation Studies, 6(1): 93-105.

Kwon, Y. (1998). A study on siting of a waste incineration plant. The Korean Association of Geographic and Environmental Education Journal, 6(2): 71-93.

Lan, Z. (1997). A conflict resolution approach to public administration. Public Administration Review, 57(1): 27-35.

Lee, J., \& Kwon, H. (1998). Conflict analysis between local governments and its management strategies in regional development: A case study of Taegu city's Wichon industrial site. Korean Policy Review, 7(3): 159-188.

Mitchell, C., \& Banks, M. (1996). Handbook of conflict resolution. New York: Pinter. 
Park, H. (2000). The impact of group conflict on public policy: The case of the Goon Po garbage incinerator. Journal of the Korean Urban Management Association, 14(1): 184-212.

Park, J. (1999). A study on the current status and the development of Saemangeum tideland reclamation project. Journal of Social Science of Chon Buk University, 25: $147-168$.

Pedersen, P. B., \& Jandt, F. E. (1996). Culturally contextual models for creative conflict management. In F. E. Jandt and P. B. Pedersen (Eds.), Constructive conflict management: Asia-Pacific cases. Thousand Oaks: Sage Publications.

Presidential Commission on Sustainable Development. (2004). A research report on establishment of conflict management system. Seoul: PCSD.

Raiffa, H. (1982). The art and science of negotiation. Massachusetts: Belknap Press of Harvard University Press.

Ross, M. H. (1993). The management of conflict: Interpretations and interests in comparative perspective. New Haven: Yale University Press.

Rubin, J. Z. (1995). Some wise and mistaken assumptions about conflict and negotiation. In J. W. Breslin and J. Z. Rubin (Eds.), Negotiation theory and practice. Cambridge, MA: Program on Negotiation at Harvard Law School.

Soh, Y. (1999). The social conditions of dilemma: A case of Wichon national industrial complex. Korean Public Administration Review, 33(1): 185-205.

Yim, J., \& Chang, W. (2004). A study on the conflict of unfavorable facilities between local governments: Cases of construction for Cheongju, Cheongwon waste landfills. Korean Policy Science Review, 8(1): 291-315.

Yoo, T., Choi, Y., \& Kwon, J. (2004). The Sapaesan tunnel of Seoul beltway. Journal of the Korean Society of Civil Engineers, 52(5): 15-25. 


\section{Appendix Table 1. The Case of the Express Railway on Cheonsung Mountain}

\begin{tabular}{|c|c|}
\hline Background & $\begin{array}{l}\text { The proposed second phase of construction of the national express } \\
\text { railway, covering the segment from Daegu to Busan city, involved } \\
\text { building tunnels through Cheonsung and Geumjung mountains, } 13.2 \mathrm{~km} \\
\text { and } 12.5 \mathrm{~km} \text { long respectively. Environmentalists and Buddhist monks } \\
\text { argued that the tunnels would damage the wetland on Cheonsung plateau } \\
\text { and seriously disturb the activities of the temples on the mountain. }\end{array}$ \\
\hline 2002 January & $\begin{array}{l}\text { The construction plan for the Daegu-Busan segment is announced by } \\
\text { Korea High Speed Rail Authority (KHSRA) of the Ministry of Construction } \\
\text { and Transportation (MOCT). }\end{array}$ \\
\hline 2002 January & $\begin{array}{l}\text { Monks and } 60 \text { environmental groups launch a national march and } \\
\text { circulate a petition, aiming for } 1 \text { million signatures. Citizens Committee } \\
\text { Against Railway Tunnel (CCART) is formed by citizen and religious } \\
\text { groups in the Busan area and periodically holds sit-ins, rallies, and } \\
\text { demonstrations. }\end{array}$ \\
\hline 2002 May 6 & $\begin{array}{l}\text { The Busan Chapter of the Korean Federation of Environmental } \\
\text { Movements (KFEM) and six citizen groups set up a camp in Busan } \\
\text { Railway Station for sit-in demonstrations. }\end{array}$ \\
\hline 2002 May 14 & $\begin{array}{l}\text { Religious and citizen groups attempt to visit the president's office to } \\
\text { submit a petition but fail. }\end{array}$ \\
\hline 2002 July 19 & Scholars, specialists, and citizen groups visit the tunnel site. \\
\hline 2002 July 24 & Monks stage "3 Steps, 1 Bow" march, make a public statement. \\
\hline 2002 July 27 & $\begin{array}{l}\text { The vice minister of MOCT meets with citizen and religious representatives } \\
\text { and agrees to form a joint committee to reexamine the railway route. The } \\
\text { mayor of Busan requests to redo the environmental impact assessment. }\end{array}$ \\
\hline 2002 September 10 & $\begin{array}{l}\text { A public forum is held by CCART on setting up a joint committee } \\
\text { composed of citizens and government officials to reexamine the } \\
\text { railway route. }\end{array}$ \\
\hline 2002 September 26 & Monthly street demonstrations begin. \\
\hline 2002 November & KHSRA invites bids for the construction project. \\
\hline 2002 November 22 & $\begin{array}{l}\text { Negotiations to set up a joint committee fail to reach an agreement and } \\
\text { are terminated. }\end{array}$ \\
\hline 2002 December & $\begin{array}{l}\text { Presidential candidate Rho Moo Hyun makes a campaign promise to } \\
\text { annul the tunnel construction plan. }\end{array}$ \\
\hline 2003 January 23 & $\begin{array}{l}\text { The president's office announces that all railway construction activities } \\
\text { will be postponed until a joint committee is set up. }\end{array}$ \\
\hline 2003 January 28 & $\begin{array}{l}\text { A statement demanding annulment of the tunnel construction plan is } \\
\text { signed by } 1,000 \text { leaders from all sectors in the Busan metropolitan area. }\end{array}$ \\
\hline 2003 February 4 & $\begin{array}{l}\text { MOCT reverses position and reasserts that it will proceed with } \\
\text { competitive bidding for a construction contract. }\end{array}$ \\
\hline
\end{tabular}




\begin{tabular}{|c|c|}
\hline 2003 February 5 & A Buddhist nun, Jiyul, goes on a hunger strike that lasts till April 11. \\
\hline 2003 March 8 & $\begin{array}{l}\text { The vice minister of MOCT and a presidential secretary visit Jiyul and } \\
\text { confirm that they are setting up a committee to reexamine the railway } \\
\text { route. }\end{array}$ \\
\hline 2003 April 5 & $\begin{array}{l}\text { CCART and government officials agree to annul the planned railway } \\
\text { route and form a joint committee to reexamine the route. }\end{array}$ \\
\hline 2003 May 12 & $\begin{array}{l}\text { The Committee for Railway Route Reexamination (CRRR) is formed with } \\
21 \text { members: a neutral chairperson; } 10 \text { members representing MOCT, } \\
\text { KHSRA, local government officials, and experts; and } 10 \text { members from } \\
\text { CCART, the Busan chapter of KFEM, civil society organizations, and } \\
\text { Buddhist temples. }\end{array}$ \\
\hline 2003 May 22-July 28 & $\begin{array}{l}\text { CRRR examines the planned route and two alternate routes but fails to } \\
\text { reach an agreement. A report is submitted to the prime minister. CRRR } \\
\text { is dissolved. }\end{array}$ \\
\hline 2003 August 4 & A CCART demonstration demands annulment of planned route. \\
\hline 2003 August 13 & Jiyul stages a "3000 bows" demonstration. \\
\hline 2003 September 19 & $\begin{array}{l}\text { The Joint Office for Government Policy Coordination (JOGPC) decides } \\
\text { on the originally planned route and announces that construction will be } \\
\text { resumed in a few months. }\end{array}$ \\
\hline 2003 September 26 & Buddhist monks stage a "3 Steps, 1 Bow" march. \\
\hline 2003 October 4 & Jiyul goes on a hunger strike that lasts till November 17. \\
\hline 2003 October 14 & $\begin{array}{l}\text { CCART applies to the Busan regional court for a temporary injunction } \\
\text { halting tunnel construction to protect salamanders. }\end{array}$ \\
\hline 2004 April 10 & The application for an injunction is dismissed. Construction resumes. \\
\hline 2004 June 30 & Jiyul goes on a hunger strike that lasts until August. \\
\hline 2004 July 12 & $\begin{array}{l}\text { CCART appeals for a temporary injunction. Construction is postponed } \\
\text { pending the court decision. }\end{array}$ \\
\hline 2004 September 23 & $\begin{array}{l}\text { Citizens Actions for Salamander Protection is formed by } 30 \text { citizen } \\
\text { organizations. }\end{array}$ \\
\hline 2004 November 29 & The appellate court rejects the application for an injunction. \\
\hline 2004 November 30 & Construction resumes. \\
\hline 2004 December 29 & $\begin{array}{l}\text { Jiyul goes on a 100-day hunger strike. She is shown on national television } \\
\text { periodically as her health seriously deteriorates. Citizens and netizens } \\
\text { demand that the government save her. Political figures make visits to } \\
\text { try to persuade her to end the hunger strike. }\end{array}$ \\
\hline 2005 February 14 & $\begin{array}{l}\text { Jiyul ends her hunger strike when the government promises to } \\
\text { conduct a joint environmental impact investigation with representatives } \\
\text { from CCART and KHSRA. }\end{array}$ \\
\hline 2005 March 29 & The team for the joint investigation is formed. \\
\hline
\end{tabular}




\begin{tabular}{l|l}
\hline 2006 February 28 & $\begin{array}{l}\text { The joint investigation team fails to produce a unified finding and submits } \\
\text { two different reports. }\end{array}$ \\
\hline 2006 June 2 & The Supreme Court rules the project should continue. \\
\hline 2006 November 1 & $\begin{array}{l}\text { The court finds Jiyul guilty of obstruction of public work in a suit filed by } \\
\text { the Korea Rail Network Authority. }\end{array}$ \\
\hline 2006 November 24 & Jiyul appeals. \\
\hline 2007 February 10 & The appeal is denied. \\
\hline
\end{tabular}

Appendix Table 2. The Case of the Gunpo Waste Incinerator

\begin{tabular}{|c|c|}
\hline Background & $\begin{array}{l}\text { The Ministry of Environment (MOE) decided that the primary waste } \\
\text { disposal method in Korea should change from landfills to incinerators. } \\
\text { Consequently, Gunpo city needed a waste incinerator for the new } \\
\text { housing estate constructed by the National Housing Corporation (NHC). } \\
\text { After considering two alternate sites near the old residential area, the } \\
\text { city and NHC decided on a site near the new housing estate. Residents } \\
\text { there opposed the city's decision, arguing that they had not been } \\
\text { informed that there would be a waste incinerator in their complex. }\end{array}$ \\
\hline 1990 February & $\begin{array}{l}\text { MOCT notifies NHC that a waste incinerator should be provided in } \\
\text { the housing estates it builds. NHC agrees with Gunpo city to build an } \\
\text { incinerator for the new housing estate in Gunpo and hand it over to } \\
\text { the city. }\end{array}$ \\
\hline 1991 June & $\begin{array}{l}\text { The city chooses three candidate sites, two near the old residential } \\
\text { area and one near the new housing estate. Tensions surface between } \\
\text { residents of the old and new areas. }\end{array}$ \\
\hline 1991 September & Gunpo city and NHC decide on the site near the new housing estate. \\
\hline 1991 November & $\begin{array}{l}\text { The construction plan for the incinerator is completed, and an } \\
\text { environmental impact assessment is conducted. }\end{array}$ \\
\hline 1992 December & The draft environmental impact assessment is released for public review. \\
\hline 1993 May & $\begin{array}{l}\text { Residents meet with city officials. Residents of the new housing estate } \\
\text { organize a committee to deal with the problem and stage demonstrations. }\end{array}$ \\
\hline 1994 December & $\begin{array}{l}\text { Site preparation and construction begin. There is strong opposition } \\
\text { from residents of the housing estate, and environmental and citizen } \\
\text { organizations join in the protest. }\end{array}$ \\
\hline 1995 June & $\begin{array}{l}\text { The incinerator becomes a major issue in the mayoral election. The } \\
\text { newly elected mayor declares a moratorium on incinerator construction } \\
\text { and proposes a new site selection process with resident participation. }\end{array}$ \\
\hline 1995 August & $\begin{array}{l}\text { The Citizens Autonomous Committee for Incinerator Construction (CACIC) } \\
\text { is formed with a representative from each of the twelve subdistricts and } \\
\text { four professors. A new site is selected near the old residential area. } \\
\text { Residents of that area stage violent demonstrations. The new site choice } \\
\text { is repealed, and CACIC is dissolved. }\end{array}$ \\
\hline
\end{tabular}




\begin{tabular}{l|l}
\hline 1995 August & $\begin{array}{l}\text { Massive piles of garbage accumulate in both old and new residential } \\
\text { areas as the Metropolitan Area Landfill in Kimpo refuses to take waste } \\
\text { from Gunpo. }\end{array}$ \\
\hline 1995 August & $\begin{array}{l}\text { The city forms an incinerator planning commission with the vice mayor } \\
\text { as the head. It sets up a Site Selection Committee (SSC) composed of } \\
\text { eight resident representatives, two specialists, and two government } \\
\text { officials. SSC selects two potential sites, one each in the old and new } \\
\text { housing areas, and asks the City Council to make the final decision. } \\
\text { But the City Council relegates the decision to the mayor. }\end{array}$ \\
\hline 1995 December & $\begin{array}{l}\text { The City Policy Coordination Committee in the mayor's office chooses } \\
\text { the site in the new housing area by a 21-to-3 vote. The mayor holds a } \\
\text { press conference announcing the decision. Residents of the new area } \\
\text { claim that SSC was neither representative nor objective. }\end{array}$ \\
\hline 1996 August & $\begin{array}{l}\text { Residents of the new area argue that the environmental impact assessment } \\
\text { and the site selection procedure were not properly carried out. }\end{array}$ \\
\hline $\begin{array}{l}\text { Construction of the incinerator starts. Protests continue for a while but } \\
\text { begin to lose support. Realizing that the decision cannot be overturned, } \\
\text { more citizens take interest in operation of the incinerator and other waste } \\
\text { management issues. Opposition by residents of the new area begins to } \\
\text { focus on waste reduction. With resident participation, a Waste Management } \\
\text { Committee is set up to oversee the operation of the incinerator. }\end{array}$ \\
\hline 1998 June & $\begin{array}{l}\text { The newly elected mayor announces a waste reduction plan that includes } \\
\text { measures to minimize food waste and promote recycling. }\end{array}$ \\
\hline
\end{tabular}

Appendix Table 3. Case Analysis by Settlement Methods

\begin{tabular}{l|l}
\hline \multicolumn{2}{l}{ A. Cases Resolved by Agreement } \\
\hline Cheongju and Cheongwon Regional Waste Landfill (1990-1998) \\
\hline Parties to conflict & $\begin{array}{l}\text { 1) Cheongwon residents (Committee Against the Landfill in } \\
\text { Cheongwon) vs. Cheongwon county government (which agreed } \\
\text { with Cheongju city to site the regional landfill in the county) } \\
\text { 2) Cheongju city vs. Cheongwon County (which broke its agreement } \\
\text { with the city due to residents' opposition) }\end{array}$ \\
\hline Neutrals & Choong-cheong Province \\
\hline Conventional strategies & $\begin{array}{l}\text { Petition to the minister, blocking passage of landfill endorsement by } \\
\text { county council, violent demonstrations, litigation }\end{array}$ \\
\hline ADR strategies & Mediated arbitration, compensation \\
\hline Final outcome & Agreement was reached on a landfill in Cheongwon. \\
\hline Kangnam Waste Incinerator (1992-2001) \\
\hline Parties to conflict & $\begin{array}{l}\text { Residents living near the incinerator site, Kangnam District Council, } \\
\text { environmental NGOs (Residents Against Incinerator, Citizen Coalition } \\
\text { for Metropolitan Waste Problem) vs. Seoul city and Kangnam district } \\
\text { governments }\end{array}$ \\
\hline \multicolumn{2}{|l}{} \\
\hline
\end{tabular}




\begin{tabular}{|c|c|}
\hline Conventional strategies & Petitions, demonstrations, public persuasion, legislation \\
\hline ADR strategies & Negotiation, informal meetings, citizen participation \\
\hline ADR bodies & Incinerator Management Committee \\
\hline Final outcome & $\begin{array}{l}\text { Agreement was reached that included fiscal compensation and } \\
\text { reduction of incinerator capacity. }\end{array}$ \\
\hline \multicolumn{2}{|c|}{ Kimpo Metropolitan Waste Landfill (1992-1995) } \\
\hline Parties to conflict & $\begin{array}{l}\text { Kimpo city, the site of the landfill (Citizens Against Industrial Waste in } \\
\text { Metropolitan Area Landfill) vs. governments of the metropolitan area } \\
\text { (Seoul, Inchon, and Kyung-gi province), Ministry of Environment }\end{array}$ \\
\hline Neutrals & Prime minister's Office of Government Policy Coordination \\
\hline Conventional strategies & Demonstrations, blocking transportation of waste \\
\hline ADR strategies & $\begin{array}{l}\text { Negotiations, expert's assessment of environmental impact, } \\
\text { partnership }\end{array}$ \\
\hline ADR bodies & $\begin{array}{l}\text { University professor, president of research institute, citizen oversight } \\
\text { committee }\end{array}$ \\
\hline Final outcome & Agreement was reached on a landfill for nontoxic waste. \\
\hline \multicolumn{2}{|c|}{ Gunpo Waste Incinerator (1991-2000) } \\
\hline Parties to conflict & $\begin{array}{l}\text { 1) Residents of old vs. new housing areas } \\
\text { 2) City government vs. residents }\end{array}$ \\
\hline Neutrals & Mayor's City Policy Coordination Committee \\
\hline Observer & National Housing Corporation \\
\hline Conventional strategies & Demonstrations, protests \\
\hline ADR strategies & $\begin{array}{l}\text { Resident participation in Joint Site Selection Committee and Waste } \\
\text { Management Committee }\end{array}$ \\
\hline ADR bodies & Citizens Autonomous Committee for Incinerator Construction \\
\hline Final outcome & The mayor's office chose a new site for the incinerator. \\
\hline \multicolumn{2}{|c|}{ Sapaesan Tunnel on Seoul Beltway (1997-2003) } \\
\hline Parties to conflict & $\begin{array}{l}\text { Buddhists, environmental NGOs vs. Ministry of Construction and } \\
\text { Transportation, Seoul city (Seoul Development Corporation) }\end{array}$ \\
\hline Neutrals & Prime minister's office (mediation), the president \\
\hline Conventional strategies & Petitions, demonstrations, litigation, court injunctions \\
\hline ADR strategies & $\begin{array}{l}\text { Negotiations, mediation, conciliation, public forums, workshops, } \\
\text { citizen surveys }\end{array}$ \\
\hline ADR bodies & $\begin{array}{l}\text { Route Adjustment Committee (six members recommended by each } \\
\text { side, two local government officials-failed to reach agreement), Route } \\
\text { Reevaluation Committee (five members recommended by each } \\
\text { side-failed to reach agreement) }\end{array}$ \\
\hline Final outcome & $\begin{array}{l}\text { Following a visit by the president, Buddhists conceded, assured of } \\
\text { measures for minimizing disruption by the tunnel. }\end{array}$ \\
\hline
\end{tabular}




\section{B. Cases Adjudicated by the Court}

\section{Shinpyoung Industrial Waste Incinerator (1995-2001)}

\begin{tabular}{l|l}
\hline Parties to conflict & $\begin{array}{l}\text { 1) District government and residents of incinerator site, environmental } \\
\text { NGOs vs. Busan city and Development Corporation (developer of } \\
\text { incinerator) } \\
\text { 2) Residents who agreed on compensation from the corporation vs. } \\
\text { residents who continued to oppose incinerator }\end{array}$ \\
\hline Conventional strategies & $\begin{array}{l}\text { Injunction, noncompliance with court order, school strikes, } \\
\text { demonstrations, litigation, denial of permits }\end{array}$ \\
\hline ADR strategies & Negotiation, participation, compensation \\
\hline ADR bodies & Citizen Oversight Committee \\
\hline Final outcome & $\begin{array}{l}\text { The court found residents' actions obstructive and damaging to the } \\
\text { corporation. }\end{array}$ \\
\hline
\end{tabular}

Saemangeum Tideland Reclamation Project (1996-2006)

\begin{tabular}{l|l}
\hline Parties to conflict & Coalition of environmental, citizen, and religious NGOs, including
\end{tabular} Chunla Bukdo citizens opposing the project, vs. Ministry of Agriculture, Chunla Bukdo provincial government, National Association of Citizens for Saemangeum Reclamation, and Chunla Bukdo citizens supporting the project

\begin{tabular}{l|l}
\hline Neutrals & Prime minister's Office of Government Policy Coordination \\
\hline Conventional strategies & $\begin{array}{l}\text { Public statements, resolutions, petitions, demonstrations, sit-ins, rallies, } \\
\text { ritual marches, threats of resignation by elected officials, litigation }\end{array}$ \\
\hline ADR strategies & Public forums, conciliation, joint assessment of environmental impact \\
\hline ADR bodies & $\begin{array}{l}\text { Joint Investigation Committee (twenty-one specialists, nine central } \\
\text { government officials) }\end{array}$ \\
\hline Final outcome & $\begin{array}{l}\text { There was a moratorium on the project. The court decided the project } \\
\text { should be discontinued and reexamined. That ruling was appealed, } \\
\text { and the Supreme Court ruled the project should be completed. }\end{array}$
\end{tabular}

\section{Ulsan Nuclear Power Plant Expansion (1996-2006)}

\begin{tabular}{l|l}
\hline Parties to conflict & Coalition of Ulsan residents, environmental NGOs, local governments
\end{tabular} in Ulsan area vs. Ministry of Commerce, Industry and Energy, Korea Hydro and Nuclear Power Corporation, and the mayor of Ulju County, the site of the power plant

\begin{tabular}{l|l}
\hline Conventional strategies & Petitions, demonstrations, rallies, litigation \\
\hline ADR strategies & Public forums, informal meetings \\
\hline Final outcome & Court ruled in favor of the power plant, and construction began. \\
\hline
\end{tabular}

\section{Seocho Memorial Park (2001-2005)}

\begin{tabular}{l|l}
\hline Parties to conflict & $\begin{array}{l}\text { 1) Seocho district government and residents vs. Seoul city government } \\
\text { 2) Seoul city government (under new mayor) vs. Ministry of } \\
\text { Construction and Transportation }\end{array}$ \\
\hline
\end{tabular}




\begin{tabular}{|c|c|}
\hline Conventional strategies & Demonstrations, litigation \\
\hline ADR strategies & Negotiations \\
\hline Final outcome & Court ruled the crematory should be built. \\
\hline \multicolumn{2}{|c|}{ High-Speed Railway on Cheonsung Mountain (2002-2006) } \\
\hline Parties to conflict & $\begin{array}{l}\text { Coalition of citizen, religious, and environmental NGOs vs. Ministry of } \\
\text { Construction and Transportation, Korea High Speed Rail Authority }\end{array}$ \\
\hline Neutrals & Prime minister's office, president's office, politicians \\
\hline Conventional strategies & $\begin{array}{l}\text { Demonstrations, petitions, obstruction of construction, rallies, ritual } \\
\text { marches, hunger strikes, litigation }\end{array}$ \\
\hline ADR strategies & $\begin{array}{l}\text { Public forums, mediated negotiations, conciliation, joint investigation } \\
\text { of environmental impact }\end{array}$ \\
\hline ADR bodies & $\begin{array}{l}\text { Joint Committee for Railway Route Reexamination (failed to reach } \\
\text { agreement) }\end{array}$ \\
\hline Final outcome & Supreme Court ruled the project should proceed. \\
\hline \multicolumn{2}{|c|}{ C. Cases in Which the Project Was Withdrawn } \\
\hline \multicolumn{2}{|c|}{ Wichun Industrial Complex (1991-2006) } \\
\hline Parties to conflict & $\begin{array}{l}\text { Daegu city, Citizens Committee for Wichun Industrial Complex vs. } \\
\text { Busan city, environmental NGOs, Citizens Against Wichun Industrial } \\
\text { Complex }\end{array}$ \\
\hline Neutrals & $\begin{array}{l}\text { Politicians, president's office, prime minister's Office of Government } \\
\text { Policy Coordination }\end{array}$ \\
\hline Observers & Ministry of Environment, Ministry of Construction and Transportation \\
\hline Conventional strategies & $\begin{array}{l}\text { Demonstrations, street performances, petition to central government, } \\
\text { legislation to prevent river pollution }\end{array}$ \\
\hline ADR strategies & Joint monitoring of river pollution, joint problem-solving \\
\hline ADR bodies & $\begin{array}{l}\text { Committee on Nakdong River Protection and Wichun Industrial } \\
\text { Complex (three central government officials, six local government } \\
\text { officials, six regional representatives, four specialists, three NGO } \\
\text { members, director of the Office of Government Policy Coordination } \\
\text { as chairperson) }\end{array}$ \\
\hline Final outcome & $\begin{array}{l}\text { The industrial complex plan was withdrawn as river protection was } \\
\text { reinforced by law. }\end{array}$ \\
\hline \multicolumn{2}{|c|}{ Construction of Dong-gang Dam (1996-2000) } \\
\hline Parties to conflict & $\begin{array}{l}\text { Ministry of Environment, environmental NGOs, area residents vs. } \\
\text { Ministry of Construction and Transportation }\end{array}$ \\
\hline Neutrals & $\begin{array}{l}\text { Expert investigation team (recommended project cancellation), prime } \\
\text { minister's office, the president }\end{array}$ \\
\hline Conventional strategies & $\begin{array}{l}\text { Media coverage, rallies, statements from international environmental } \\
\text { NGOs }\end{array}$ \\
\hline
\end{tabular}




\begin{tabular}{|c|c|}
\hline ADR strategies & Joint investigation, expert findings, interagency meetings \\
\hline ADR bodies & Joint Evaluation Team (failed to reach agreement) \\
\hline Final outcome & The president decided to cancel the project. \\
\hline \multicolumn{2}{|c|}{ Buan Wido Nuclear Waste Repository (2003-2004) } \\
\hline Parties to conflict & $\begin{array}{l}\text { Coalition of religious and environmental NGOs, Buan residents } \\
\text { opposing the project vs. Ministry of Commerce, Industry and Energy, } \\
\text { Korea Hydro and Nuclear Power Corporation, Buan residents } \\
\text { supporting the project }\end{array}$ \\
\hline Neutrals & $\begin{array}{l}\text { Korean Medical Association, Ministry of Home Affairs, } \\
\text { prime minister's office }\end{array}$ \\
\hline Conventional strategies & Demonstrations, rallies, school strikes, hunger strikes, violence, arrests \\
\hline ADR strategies & $\begin{array}{l}\text { Public hearings, forums, citizen survey, experts' opinions, } \\
\text { joint problem-solving }\end{array}$ \\
\hline ADR bodies & $\begin{array}{l}\text { Joint Council for Buan Solution (five members from the Buan } \\
\text { Coalition, five government officials, neutral chairperson-failed to } \\
\text { reach agreement) }\end{array}$ \\
\hline Final outcome & $\begin{array}{l}\text { The Ministry of Commerce, Industry and Energy decided to repeal } \\
\text { the project. }\end{array}$ \\
\hline
\end{tabular}

